\title{
Motivation as the Mediator in Relationship between Non-verbal Communication of Arabic Language Teachers and Student Learning Outcomes
}

\author{
Zawawi Ismail,", $^{1,}$ Nordin Halias ${ }^{1}$, Rahimi Md Saad², Mohd Faisal Mohamed ${ }^{2}$ \\ ${ }^{1}$ Department of Language and Literacy Education, Faculty of Education, University of Malaya, Malaysia \\ ${ }^{2}$ Department of Educational Foundations and Humanities, Faculty of Education, University of Malaya, Malaysia
}

Received September 4, 2019; Revised January 10, 2020; Accepted February 3, 2020

Copyright $\odot 2020$ by authors, all rights reserved. Authors agree that this article remains permanently open access under the terms of the Creative Commons Attribution License 4.0 International License

\begin{abstract}
Effective communication requires a strong combination between verbal and nonverbal communication which is one of the skills that need to be mastered by a teacher. The estimate of 65-70 percent of message in communication is obtained by nonverbal and only 30-35 percent is obtained through speech. This study is aimed at investigating the impact of NVC practice of Arabic language teachers on the motivation of students and their learning outcomes in Arabic language in Malaysia. Quantitative study used a survey questionnaire and was involved a population of 84,841 students. Sampling was done through stratified random sampling and only 750 students were chosen in all over Malaysia as respondents. The SEM model was analysed using the approach by Baron and Kenny (1986). The findings show that the relationship $\mathrm{NVC} \rightarrow$ motivation in students was significant $(\beta=.133, p<$ $0.01)$, NVC $\rightarrow$ learning outcome $(\beta=.350, p<0.01)$, motivation $\rightarrow$ learning outcome $(\beta=.439, p<0.01)$. In the test of indirect effect (mediator), the findings show that motivation was statistically proven through the Sobel test $(\beta=0.133$, Sobel Test $=4.68, \mathrm{SE}=0.01, p<0.01)$ as the mediator in the relationship between NVC and learning outcome. Hence, the result shows that, the higher the motivation possessed by the students the better their learning outcome in Arabic language. Therefore, inevitably the teachers play vital roles during teaching and learning to use more NVC approach to enhance the higher learning outcomes for students in Arabic language learning.
\end{abstract}

Keywords Teaching Communication, Nonverbal Communication, Motivation, Teaching of Arabic

\section{Introduction}

Studies on teaching communication have been carried out by many researchers for many decades (Kendon, 1981). Nevertheless most studies on teaching communication focus more on the verbal communication aspect of teachers whereas studies on NVC in teaching are rarely carried out (Juliana Othman, 2007; Nur Shafrin Ahmad, Rahimi Che Aman, \& Fadzilah Amzah, 2009). It is generally accepted that human communication can occur in two main ways, namely verbal and nonverbal communication (Floyd, 2009; Heun \& Heun, 1975; Richmond \&McCroskey, 2000) yet less attention is paid to nonverbal elements. This is because verbal communication occurs through speech or spoken language (Asmah Omar, 1988; Mustafa Daud, 1996; Noor Hasnoor Mohamad Nor, 2001) while nonverbal communication. (NVC) does not involve speech or utterances.

NVC refers to any resource other than what is verbalized that can deliver a communicative message (Abdullah Hassan, 1980; Heun, \& Heun, 1975; Floyd, 2009; Goodhal, Goodhal, \& Schiefelbein, 2010; Kendon, 1981; Kifayat Aghayeva, 2011; Sperder \& Wilson, 1999 ). Although the two forms of communication are quite different in the terminology aspect they are interrelated and strengthen each other (McCroskey, Richmond, Sallinen, Fayer, \& Barraclough, 1995; Mehrabian, 1981). NVC although regarded as the most basic and primitive human communication delivers the most messages (K. Sri Gayatthrdevi \& D. Sudharani Ravindran 2010) especially in communication (Abdullah Hassan \& Ainon Mohd, 2002; Maimunah Osman, 2000) 
Terminology of NVC is generally defined as any resource that can deliver a message other than what is verbalized (Kendon, 1981). No consensus exists on the classification and number of channels of NVC among its researchers (Muhammad Al Amin Musa Ahmad, 2003; Zulkifli Abdullah, 1999). Researchers use a different definition based on the direction of their research (Floyd, 2009; Kendon, 1981; Pogue \& Ahyun, 2006). However, as related to education there are usually ten channels of NVC most often debated, namely: (i) physical appearance, (ii) body movement, (iii) environment, (iv) facial expression, (v) eye contact, (vi) variation in tone, (vii) personal distance, (viii) use of time, (ix) touch and (x) olfactics (Richmond \& McCroskey, 2000).

In efforts to create effective communication NVC must be given attention because of its dominant messages. Researchers claim that 80 percent of the overall message in a human communication is transferred through NVC channel of body movement, 14 percent through tone NVC and only 6 percent through words (Nelson, 1997). But Floyd (2009) opined that 80 percent is rather extreme. Hence for Floyd (2009) the estimate of 65-70 percent of message is obtained by nonverbal means in a communication is ideal and only the balance of between 30-35 percent is obtained through speech. Although this estimate of the NVC effect is reduced, in fact the estimate by Floyd (2009) still illustrates the strength of the NVC message in an effective communication. NVC is very influential in communication; as studies have shown, in a face to face communication, listeners will pay attention to as much as 55 percent of the conversation time to nonverbal signals of the communicator, 38 percent to changes in tone of voice and only 7 percent to the speech content itself (Asha Kaul, 2007). Hence it will not be unusual if, in the context of teaching, NVC of the teacher can improve cognitive and affective learning outcomes (Paul \& Lawrence, 2001).

\section{Nonverbal Communication and Effective Teaching}

Effective communication is one of the skills that need to be mastered by a teacher of quality. Effective communication requires a strong combination between verbal and nonverbal communication (Syed Ismail Syed Mustafa \& Ahmad Subki Maskon, 2010). Richmond and McCroskey (2000) and Devito (2007) emphasize that to create effective teaching and achieve optimum learning outcomes, a teacher must know, master, and possess both types of communication, because each complements the other; in fact NVC influences the effectiveness of the teacher's verbal communication.

In nonverbal terms, teachers can exhibit communication and behaviour that is positive when interacting with students. Positive nonverbal communication can be through smiling, nodding, eye contact, shaking hands and hugging (Collis \& Dalton 1997). This behaviour plays a role in delivering a certain message such as strengthening the verbal communication, manifesting charisma, showing confidence (Kifayat Aghayeva, 2011) besides translating and illustrating the verbal message (Devito, 2007). Indeed, for better understanding of the actual verbal message, both aspects of verbal and NVC must be mastered well (Argyle, 1979; Kamarul Azmi Jasmi \& Ab.Halim Tamuri, 2007).

Knowledge and application of $\mathrm{NVC}$ is important in a teacher's career. NVC facilitates the teacher's teaching (Muhammad Azhar Zailani, 2007), attracts the student's attention (Burrough, 2007) and lessens miscommunication. Miscommunication during teaching can also arise because of teacher unawareness of NVC elements such as style, attire and behaviour of teacher that is not appealing to the student during the teaching and learning process (Lau \& Chan, 1972). Apart from influencing communication effectiveness, teacher NVC also has direct effect on shaping attitudes (Burrough, 2007), motivation and learning outcomes (Macedonia \& Knosche, 2011). To verify the relationship or influence between NVC and Arabic language learning outcomes, one hypothesis was put forward:

$\mathrm{H} 1$; There is a significant relationship between NVC practice by the teacher and learning outcomes in Arabic language.

This illustrates that teachers of Arabic language have NVC competency and this competency influences the effectiveness of their Arabic language teaching. There are many channels of NVC. In this study, to identify the relationship, we use ten NVC channels, namely: 1) physical appearance, 2) Kinesics, 3) Chronemics, 4) Haptics 5) Facial expression, 6) Oculesics, 7) Proxemics, 8) Paralinguistics, 9) Environment/space, and 10) Olfactics. All these channels were chosen for study because they are often related to teaching (Richmond \& McCroskey, 2000).

\section{Influence of Teacher NVC in Arabic Language Student Motivation}

Motivation is a term derived from the Latin "Movere". It refers to the object of effort made by persons to their needs such as food and water (Asmawati Desa, 2009). Motivation is also a psychological process or invisible behaviour that arouses humans and moves them to continue acting in order to achieve a goal (Abu Bakar Hamid, Rusmala Mohd Daud, \& Siti Nabiha Abdul Khalid, 2007). For this reason, to Reeve (2009) motivation is an internal process based on need, cognition and emotion that subsequently becomes the source of energy directing a certain behaviour. Motivation is an invisible variable in the individual that motivates in the direction of initiating and defending behaviour to achieve certain objectives.

Although motivation is important, motivating students is 
not an easy task (S.Nasution, 1995). Noraini Idris (2005) stated that an effective relationship and teaching by the teacher can influence students' motivation indirectly. Touching on the same issue, Ramlah Jantan and Mahani Razali (2004) stated that the teacher plays a role in arousing motivation in students for more effective learning. Hence, according to Blair, Jones, and Simpson (1991), teachers who fail are often those who do not consider the factor of learner motivation. Two types of motivation often associated with learning are intrinsic and extrinsic motivation (Blair et al., 1991; Mok, 2003; S. Nasution, 1995). Intrinsic motivation refers to inner motive while extrinsic motivation refers to incentive (Blair et al., 1991; Kamarudin Husin, 1997). To confirm the relationship between teacher NVC and motivation for learning, a hypothesis was created, namely:

- H1: Teacher NVC has a positive impact on student motivation for learning

In the learning context, student motivation is very important. This is because motivation influences the preferences of the student to take actions in learning to achieve motives that may be an interest or to get an incentive such as performance or good grades (Ramlah Jantan \& Mahani Razali, 2004). Without high motivation the readiness of students will fall and learning will not occur (Mok, 2011). This is because an important factor in determining the learning process is the desire [motivation] of the individuals themselves to continue learning (Shahabuddin Hashim, Rohizani Yaakub, \& Mohd Zohir Ahmad, 2003). Motivation to learn is also important because students who have high aspiration and motivation will have positive attitude toward a subject and vice versa (Zuraida Mohamed, 2011).To confirm the above, two hypotheses will be forwarded:

- H2: A significant relationship exists between the practice of teacher NVC and student learning outcomes
- H3: A significant relationship exists between student motivation and learning outcomes

Motivation is necessary in the learning process (Fidelis, 2006) so that positive change in behaviour can be maintained (Mohamad Salleh Lebar, 1999). Students who are motivated will be: (a) more dedicated, more enthusiastic and committed, (b) be more interested in learning, (c) listen and pay full attention to the lesson, (d) be active in and outside the class, (e) easily move and accept teachers' instructions, (f) be independent and (g) like to give views and opinions in class (Ramlah Jantan \& Mahani Razali, 2004). Hence motivation is the mediator between teaching and learning (Mok, 2011). The role of motivation in this relationship is clarified in Figure 1.

The study shows that a relationship exists between teacher NVC and student motivation. This occurs because the findings show that learner motivation will be high if teacher NVC is high and vice versa (McCroskey, Richmond, \& Bennet, 2006; Pogue \& Ahyun, 2006). The study by Mat Noor Su (1998) on Arabic language students also found the same phenomenon; the research sample was found to be highly motivated and enthusiastic to attend the class, complete their tasks and take part in language activities because they were influenced by the teachers' behaviour. Hence, teachers need to encourage motivation in learners because according to Chek Mat (2005), motivation results from right guidance and continuous encouragement. For this reason, motivation is the mediator variable in this study. This was done based on empirical proof in the studies carried out. To verify this claim, another hypothesis was offered, namely:

- H4: Student motivation is the mediator in the relationship between NVC practice of the teacher and learning outcomes

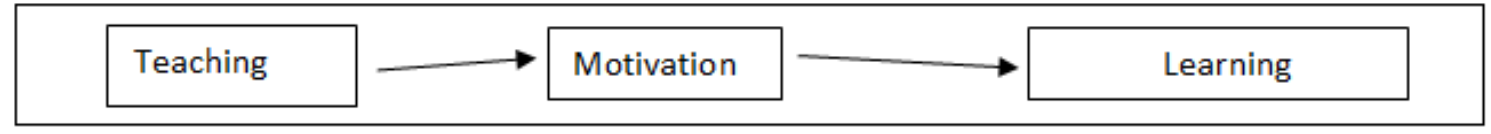

Figure 1. Model of the relationship between teaching, motivation and learning (Mok, 2011) 


\section{Research Questions}

In general the study is aimed at investigating the impact of NVC practice of Arabic language teachers on the motivation of students and their learning outcomes in Arabic language in Malaysia. Hence the following research questions are the focus of the study. The research questions are built based on the hypotheses suggested:

1. Is there a significant relationship between NVC practice by teachers and motivation in students?

2. Is there a significant relationship between teacher NVC practice and learning outcomes?

3. Is there a significant relationship between student motivation and learning outcomes?

4. Is student motivation a mediator in the relationship between teacher NVC and learning outcomes?

\section{Research Methodology}

This study was carried out as a quantitative study using a survey design. The study used a questionnaire as the instrument for obtaining data. Questionnaire was used because it has its strengths and is appropriate for measuring opinion, attitude and behaviour (Ary, Jacob, \& Razavieh, 1985; Fullan, 2001; Hsiao \& Fisher, 2002). Hence, questionnaire is appropriate for use in this study because the study is trying to measure as well as illustrate the real situation of NVC practice by teachers.

The questionnaire was built by the researchers by adopting and modifying from questionnaires by previous researchers. The items for NVC construct were adapted from the CARNIM (Culturally-Adapted Revised Nonverbal Immediacy Measure) questionnaire by Hinkle (2009), NIS-S (Nonverbal immediacy Scale- Self Report) by Richmond, McCroskey, and Johnsons (2003), Nonverbal Behaviour In Interpersonal Relations (Richmond \& McCroskey, 2000), Revised Nonverbal Immediacy Measure (RNIM)(McCroskey et al., 1995), Nonverbal Immediacy Scale-Self Report (NIS-S) and Nonverbal Immediacy Scale-Observer Report (NIS-O) by Richmond, McCroskey, and Johnsons (2003). Items in the questionnaire were reviewed and rebuilt by the researchers by adopting and modifying in line with the research objectives and the literature. Items modified were reviewed by a panel of experts for validation. A pilot study was carried out to evaluate the instrument reliability.

For the variable motivation, the measured variables were intrinsic and extrinsic motivation (Blair et al., 1991; Mok,
2003; S.Nasution, 1995) and each was measured by five items. Items for the motivation construct were filtered and adapted from the Attitude/Motivation Test Battery (AMTB) (Gardner, 2004) and Students' Motivation towards Science Learning (SMTSL) (Hsiao-Lin, Chi-Chin, \& Shyang-Horng, 2005). Learning outcome was measured by items built based on Bloom's taxonomy namely Cognitive, Affective and Psychomotor achievement.

All items were tested for validity and reliability. Reliability was good, as shown by the Cronbach alpha value of .96. Item validity was done through confirmatory factor analysis (CFA) through the measurement model using structural equation modelling (SEM). Analysis results of CFA showed that the measured model fit well for all constructs whether the $\mathrm{NVC}$ construct $(\mathrm{CMIN} / \mathrm{df}=$ 2.264, $\mathrm{CFI}=938, \mathrm{GFI}=.903, \mathrm{TLI}=.931$ and RMSEA $=.041)$, motivation construct $(\mathrm{CMIN} / \mathrm{df}=4.334, \mathrm{CFI}$ $=.976, \mathrm{GFI}=.973, \mathrm{TLI}=.965$ and $\mathrm{RMSEA}=.067)$ and learning outcome construct $(\mathrm{CMIN} / \mathrm{df}=4.435, \mathrm{CFI}=.968$, GFI $=.944$, TLI $=.960$ and RMSEA $=.068)$. All the constructs had a value of CMIN/DF below 5, index of CFI, GFI and TLI above .9 and RMSEA below .08 as in the standards recommended (Hair, Joseph, Tatham, Anderson, Black, \& Babin, 2006; Imam Ghozali, 2008)

This study involved a population of 84,841 students. This number is the total of Arabic language students in 55 SMKA and 143 SABK all over Malaysia (Bahagian Pendidikan Islam, 2012). From this total, 750 were chosen as the research sample. Sampling was done by stratified random sampling according to zone. For this purpose, all schools including those in Sabah and Sarawak were divided into five zones. This method increases the probability of selecting a representative sample overall. Besides that, this method also facilitates in sample selection and data collection.

Data were collected and analysed using SPSS version 18 and AMOS version 18. AMOS was used for statistical analysis by structural equation modelling (SEM). The SEM model was analysed using the approach by Baron and Kenny (1986). To examine the model fit, the fit indices (i). CMIN/df, (ii) CFI, (iii) TLI, (iv) GFI and (v) RMSEA (Hair, Tatham, Anderson, Black, \& Babin, 2006; Imam Ghozali, 2008) were used. The role of motivation as a mediator was confirmed using Monte Carlo method (MacKinnon, Lockwood, Hoffman, West, \& Sheets, 2002; Preacher \& Selig, 2012). For this purpose an "a priori" model was proposed (Hoyle, 1995) and created as in the following Figure 2:

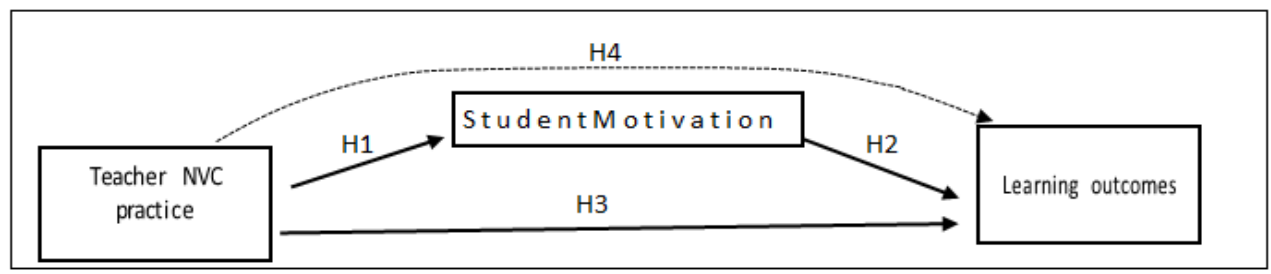

Figure 2. The a priori model for motivation as a mediator in the relationship between teacher NVC and Student Arabic language learning outcomes 
Based on the a priori model and modified according to the approach by Baron and Kenny (1986), four hypotheses put forward before this were re-submitted for measurement using structural equation modelling (SEM); namely:

- $\mathrm{H} 1$ - There is a significant relationship between NVC and student motivation.

- $\mathrm{H} 2$ - There is a significant relationship between student motivation and learning outcomes.

- $\quad \mathrm{H} 3$ - There is a significant relationship between NVC and learning outcomes.

- H4 - Motivation plays a role as the mediator in the relationship between NVC and learning outcomes.

In this study, $\mathrm{H} 4$ predicts that motivation is the mediator between learning outcomes of Arabic language students and teacher NVC. This prediction means the relationship between NVC and learning outcome indirectly is influenced by motivation as the intervening variable or mediator (NVC $\rightarrow$ motivation $\rightarrow$ learning outcome). Before testing of $\mathrm{H} 4$, the testing of $\mathrm{H} 1, \mathrm{H} 2$ and H3 must be done first. This testing is done because according to the approach by Baron and Kenny (1986) all variables to be tested must be shown to have a direct and significant effect first as a precondition for testing as a mediator in an indirect relationship.

\section{Discussion on Findings}

The findings are discussed according to the research questions and hypotheses put forward. We begin with discussion on: 1) relationship between teacher NVC and student motivation, 2) relationship between student motivation and learning outcomes, 3) relationship between $\mathrm{NVC}$ and learning outcomes and 4) the place of motivation as mediator.

Testing of hypothesis $\mathrm{H} 1$ predicts that in the direct effect, there is a significant relationship between NVC and motivation of Arabic language students. In this relationship, NVC is the exogenous variable while motivation is the endogenous variable. Results of analysis by modelling of the direct relationship shows a significant relationship at the 0.001 level between $\mathrm{NVC}$ and motivation $(\beta=.133$, C.R $=5.298, p<0.001)$. Hence the hypothesis that predicts a significant relationship and direct effect of NVC on motivation is supported and accepted.

Table 1. Regression Weights: (Group number 1 - Default model) H1

\begin{tabular}{|c|c|c|c|c|c|c|c|}
\hline & & & Estimate & S.E. & C.R. & $p$ & Label \\
\hline MOT & $<---$ & K_NV & .133 & .025 & 5.298 & $* * *$ & par_6 \\
\hline
\end{tabular}

Apart from being significant, the findings also show the nature of relationship between the two constructs is positive $(\beta=.133)$. This kind of relationship is direct which means if the teacher has a high NVC score the student's motivation score will also be high. This finding also shows that the more the teacher uses NVC during teaching, the higher the student's motivation in learning Arabic language. This finding is aligned with that of McCroskey et al. (2006) as well as Pogue and Ahyun (2006) who also found a positive and significant relationship between teacher nonverbal communication and motivation.

Testing of hypothesis $\mathrm{H} 2$ predicted that in the direct effect, there exists a significant relationship between motivation and learning outcome of Arabic language students. In this relationship, motivation is the exogenous variable while learning outcome is the endogenous variable. The results of analysis by modelling in the direct relationship shows that a significant relationship exists at the 0.001 level between NVC and motivation $(\beta=.439$, $\mathrm{C} . \mathrm{R}=10.605, p<0.001)$. Hence the hypothesis predicting a direct effect between motivations and learning outcome is supported and accepted.

Table 2. Regression Weights: (Group number 1 - Default model) h4

\begin{tabular}{|c|c|c|c|c|c|c|c|}
\hline & & & Estimate & S.E. & C.R. & $p$ & Label \\
\hline HAS & $<---$ & MOT & .439 & .041 & 10.605 & $* * *$ & par_7 \\
\hline
\end{tabular}

Besides being significant, the findings also show the nature of relationship between the two constructs is positive $(\beta=.439)$. This relationship is a direct relationship; it means if the student has high motivation the score for learning outcome will also be high, and low motivation will result in lower score for learning outcome. This shows that the higher the motivation possessed by the students the better their learning outcome in Arabic language.

Testing of the hypothesis $\mathrm{H} 3$ predicts that in the Direct Effect, there is a significant relationship between NVC and learning outcome of Arabic language students. In this relationship, $\mathrm{NVC}$ is the exogenous variable while learning outcome is the endogenous variable. The results of analysis by modelling on the direct effect shows that a significant relationship exists at the 0.001 level between NVC and learning outcome $(\beta=.350$, C.R. $=7.925, p$ $<.001)$. Hence the hypothesis predicting a significant relationship in direct effect of $\mathrm{NVC}$ on learning outcome is supported and accepted.

Table 3. Regression Weights: (Group number 1 - Default model) h3

\begin{tabular}{|c|c|c|c|c|c|c|c|}
\hline & & & Estimate & S.E. & C.R. & $p$ & Label \\
\hline HAS & $<---$ & K_NV & .350 & .044 & 7.925 & $* * *$ & par_12 \\
\hline
\end{tabular}

Besides being significant, the findings also show that the relationship between the two constructs is positive ( $\beta$ $=.350$ ). The direct relationship means that if the teacher NVC score is high then the score for learning outcome will also be high; and vice versa. This finding shows that the more teachers use NVC during their teaching the higher the learning outcomes obtained by the students in their Arabic language learning. 


\section{Distribution of Indirect Effect}

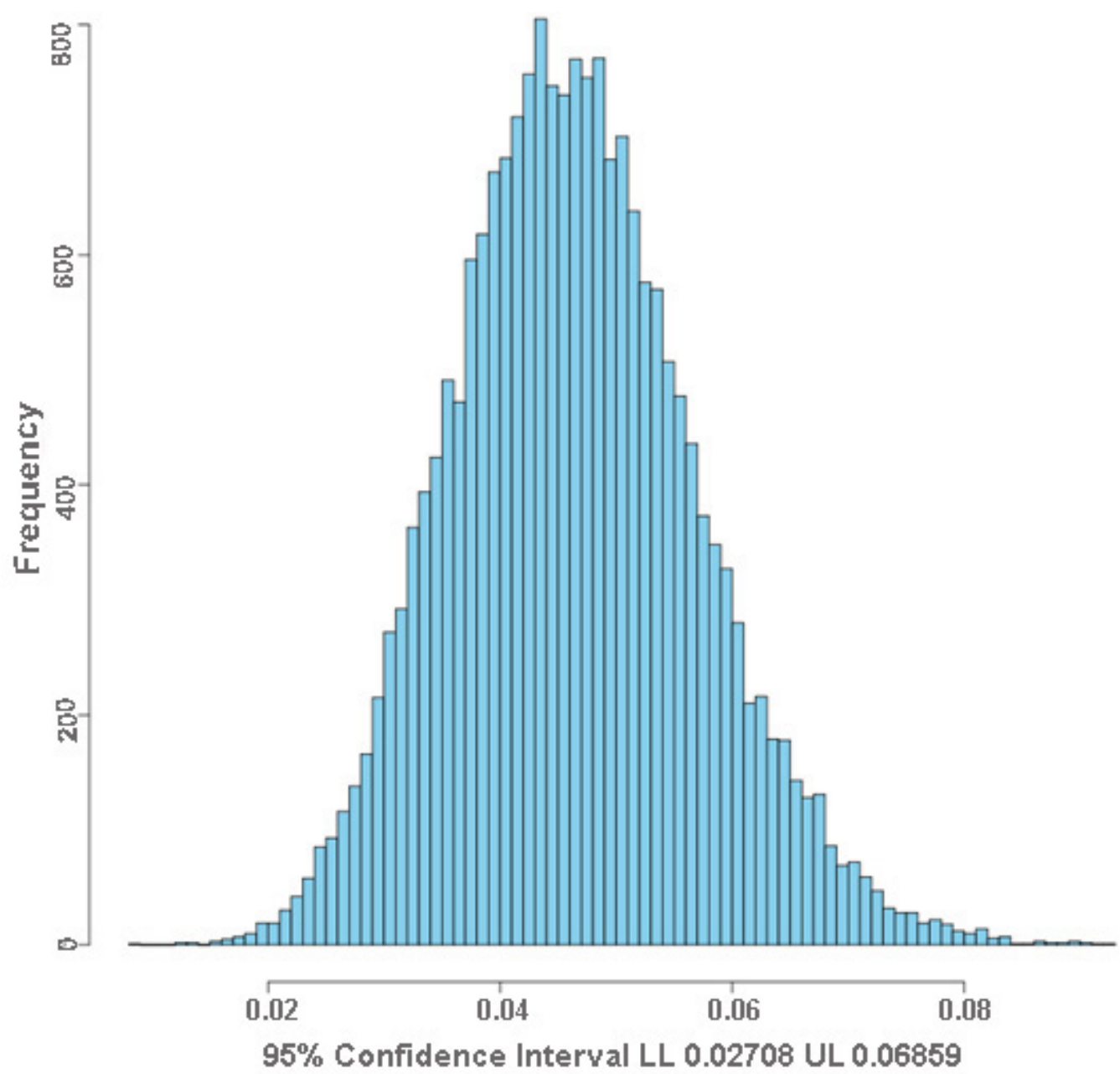

Figure 3. Histogram Monte Carlo bootstrapping showing motivation as the mediator in the relationship between NVC and learning outcomes

Table 4. Comparison between the value of direct effect and indirect effect between NVC and learning outcome

\begin{tabular}{|c|c|c|c|c|c|c|c|c|}
\hline Model & & & & Estimate & S.E. & C.R. & $p$ & Label \\
\hline M1 & HAS & $<---$ & K_NV & .337 & .044 & 7.617 & $* * *$ & par_13 \\
\hline M3 & HAS & $<---$ & K_NV & .276 & .041 & 6.703 & $* * *$ & par_14 \\
\hline
\end{tabular}

Hypothesis 4 predicts that motivation is the mediator in the indirect relationship between NVC and learning outcome. The results of $\mathrm{H} 1$ to $\mathrm{H} 3$ testing have proven that in the indirect effect, there exists a significant relationship between all variables tested. This result has qualified hypothesis 4 for subsequent testing according to the approach by Baron dan Kenny (1986).

Existence of a mediator in this relationship is measured by the Sobel Test and Monte Carlo test. Sobel Test shows that there exists a mediator role or indirect effect $(\beta=0.133$, Sobel Test $=4.68, \mathrm{SE}=0.01, p<.01)$. Monte Carlo test
(Fig. 3) also shows that motivation functions as a moderator in the relationship between NVC and learning outcome. This decision was made based on the Monte Carlo histogram showing there is no value of 0 between LL and UL. The reading of LL shows a value of 0.02 while UL shows a value of 0.06 . Because these two values of UL and LL are positive and no 0 value was found between LL and UL; with this finding, the function of motivation as mediator between the relationships is statistically proven.

The position of motivation whether as full mediator or partial mediator is determined by looking at the 
significance value and beta. In the direct relationship meaning without the presence of motivation as mediator (Model M1) and also in the indirect relationship after putting in motivation as mediator (Model M3), it was found that the relationship between NVC and learning outcome was still significant at the 0.001 level. Nevertheless, it was found that the Beta value had fallen from 0.321 to 0.151 . This result (Kenny, 2014) shows that motivation is the partial mediator in the relationship between NVC and learning outcomes. This is because the relationship between NVC and outcome was still significant after the appearance of motivation as a mediator but there occurred a decrease in value of Beta (Baron \& Kenny, 1986). With this result, H4 that predicts motivation as the mediator of the relationship between NVC and learning outcome is accepted and motivation is hence regarded as partial mediator.

This finding strengthens the theory that the teacher is the catalyst in motivating students. Among others, Noraini Idris (2005) stated that the relationship and teaching of an effective teacher influences student motivation indirectly. According to Noraini Idris (2005) further, the factor of teacher nonverbal behaviour such as enthusiasm, positive relationship such as ability to persuade, showing caring attitude, being aware of students' problems and always giving encouragement can create a close positive relationship, and subsequently motivate the student. Touching on the same issue, Ramlah Jantan and Mahani Razali (2004) stated that the teacher plays a role in arousing motivation in students for more effective learning. Thus the NVC aspect is one aspect deserving attention from Arabic language teachers.

\section{Conclusions}

The findings have proven that a relationship exists between NVC of Arabic language teachers and the shaping of student motivation. This finding is aligned with Noraini Idris (2005) and Ramlah Jantan and Mahani Razali (2004) that teacher nonverbal behaviour is able to motivate students. This study also proves that motivation is a partial motivator. This finding shows that learning can occur, but with existence of motivation encouraged by teacher NVC the learning improves. This finding is supported by the statement of Zaidatol Akmaliah Lope Pihie (2001) that motivation gives momentum to behaviour toward greater success. Hence, according to the findings of the study, teachers of Arabic language should practice all channels of NVC namely 1) Physical appearance, 2) Kinesics, 3) Chronemics, 4) Haptics 5) Facial expression, 6) Oculesics, 7) Proxemics, 8) Paralinguistics, 9) Environment/space and 10) Olfactics in their teaching. Teachers skilled in NVC have the ability to raise students' motivation and consequently facilitate Arabic language learning.

\section{REFERENCES}

[1] Abdullah Hassan. (1980). Linguistik Am untuk guru Bahasa Melayu. kuala Lumpur: Fajar Bakti.

[2] Abdullah Hassan, \& Ainon Mohd. (2002). Kemahiran interpersonal untuk guru (Edisi ke-2). Bentong: PTS.

[3] Abu Bakar Hamid, Rusmala Mohd Daud, \& Siti Nabiha Abdul Khalid. (2007). Asas Pengurusan Perniagaan (2nd ed.). Sintok: Universiti Utara Malaysia.

[4] Argyle, M. (1979). New developments in the analysis of Social Skills. In A. Wolfgang (Ed.), Nonverbal behavior: Applications and cultural implications. New York, NY: Academic Press.

[5] Ary, P., Jacob, L., \& Razavieh. (1985). Introduction to research in education (3rd ed.). New York,NY: Holt, Rinehart \& Winston.

[6] Asha Kaul. (2007). Effective business communication. New Delhi, India: Prentice Hall.

[7] Asmah Omar. (1988). Bahasa dan alam pemikiran Melayu. Kuala Lumpur: Dewan Bahasa dan Pustaka.

[8] Asmawati Desa. (2009). Psikologi untuk golongan profesional (3rd ed.). Kuala Lumpur: McGraw- Hill.

[9] Bahagian Pendidikan Islam. (2012). Data Sekolah Agama KPM 2012. Kementerian Pendidikan Malaysia.

[10] Baron, R. M., \& Kenny, D. A. (1986). The Moderator-Mediator Variable Distinction in Social Psychological Research: Conceptual, Strategic, and Statistical Considerations. Journal of Personality and Social Psychology, 51(6), 1173-1182. Retrieved fromhttp://www. public.asu.edu/ davidpm/classes/psy536/Baron.pdf

[11] Blair, G. M., Jones, R. S., \& Simpson, R. H. (1991). Psikologi Pendidikan. (Terj. Noran Fauziah Yaakub, Ed.). Kuala Lumpur: Dewan Bahasa Dan Pustaka.

[12] Burrough, N. F. (2007). A reinvestigation of the relationship of teacher nonverbal immediacy and student compliance resistance with learning. Communication Education, 56(4), $453-475$.

[13] Chek Mat. (2005). Kursus pengurusan program: Memperkukuhkan pemahaman, pengetahuan dan kemahiran dalam mengendalikan program. Kuala Lumpur: Utusan.

[14] Collis, M., \& Dalton, J. (1997). Menjadi pelajar yang bertanggungjawab: Strategi pengurusan bilik darjah secara positif. (Terj. Abdul Rahman Yeop, Ed.). Kuala Lumpur: Institut Terjemahan Negara Malaysia Bhd.

[15] Devito, J. (2007). The interpersonal communication book (11th ed.). Boston, MA: Pearson.

[16] Fidelis E.Warumu. (2006). Belajar dan motivasi: Bagaimana mengembangkan motivasi internal. Jurnal Provitae, 2 Retrieved from http://books.google.com.my/books?hl=en\& $1 \mathrm{r}=\& \mathrm{id}=20 \mathrm{aLCZgE} 9 \mathrm{rkC} \&$ oi $=$ fnd $\&$ pg $=\mathrm{PA} 21 \& \mathrm{dq}=$ motivasi + instrumental+\&ots

[17] Floyd, K. (2009). Interpersonel communication: The whole story. New York, NY: McGraw-Hill. 
[18] Fullan, M. (2001). The new meaning of educational change (3rd ed.). New York, NY: Teachers College Press.

[19] Gardner, R. C. (2004). Attitude/Motivation Test Battery: International AMTB Research Project. Retrieved from http://publish.uwo.ca/ gardner/docs/englishamtb.pdf

[20] Goodhal, H. L. J., Goodhal, S., \& Schiefelbein, J. (2010). Business and professional communication in the global workplace. Belmont, CA: Wadsworth.

[21] Hair, J., Joseph, F., Tatham, R. L. Anderson, R. E., Black, W. C., \& Babin, B. J. (2006). Multivariate data analysis (6th ed.). Englewood Cliffs, NJ: Pearson Prentice Hall.

[22] Heun, L. R., \& Heun, R. E. (1975). Developing skills for human interaction. Columbus, $\mathrm{OH}$ : Merrill.

[23] Hinkle, lois 1. (2009). Teacher nonverbal immediacy behaviors and student-perceived cognitive learning in japan. Communications Research Reports, 15(1), 45-56.

[24] Hoyle, R. H. (1995). Structural Equation Model. Thousand Oaks, CA: Sage.

[25] Hsiao, C. S., \& Fisher, D. (2002). Teacher communication behaviour and its association with students' cognitive and attitudinal outcomes in Science in Taiwan. Journal of Research in Science Teaching, 39(1).

[26] Hsiao-Lin, T., Chi-Chin, C., \& Shyang-Horng, S. (2005). The development of a questionnaire to measure students' motivation towards science learning. International Journal of Science Education, 27(6), 639-654.

[27] Imam Ghozali.(2008). Model persamaan struktural : Konsep dan aplikasi dengan program Amos 16.0. Semarang: Badan Penerbit Universitas Diponegoro.

[28] Juliana Othman. (2007). Amalan Stretegi Pengajaran Bahasa Inggeris Di Peringkat Sekolah Rendah. Jurnal Pendidikan, 27(1), 44-48.

[29] Kamarudin Husin. (1997). Psikologi Bilik Darjah: Asas Pedagogi. Kuala Lumpur: Utusan.

[30] Kamarul Azmi Jasmi, \& Ab.Halim Tamuri. (2007). Pendidikan Islam: Kaedah pengajaran dan pembelajaran. Johor Bahru: Universiti Teknologi Malaysia.

[31] Kendon, A. (1981). Nonverbal communication: Interaction and gesture. The Hague: Mouton Publisher.

[32] Kifayat Aghayeva. (2011). Different aspect of intercultural nonverbal Communication. Khazar Journal of Humanities and Social Sciences, 14(2), 53-62. Retrieved from http://h dl.handle.net/123456789/1361

[33] Lau, K. C., \& Chan, B. F. (1972, April). Komunikasi pengajaran. Masalah Pendidikan.

[34] Macedonia, M., \& Knosche, T. R. (2011, December). Body in mind: How gestures empower foreign language learning.Mind, Brain, And Education,5(4), 196-211.

[35] MacKinnon, D. P., Lockwood, C. M., Hoffman, J. M., West, S. G., \& Sheets, V. (2002). A comparison of methods to test mediation and other intervening variable effects. Psychological Methods, 7(1), 83-104. doi:10.1037/1082-9 89X.7.1.83

[36] Maimunah Osman. (2000). Pengucapan awam yang berkesan. Kuala Lumpur: Institut Terjemahan Negara Malaysia.

[37] Mat Noor Su. (1998). Keberkesanan Kursus Bahasa Arab Komunikasi Peringkat Asas. (Disertasi Sarjana yang tidak diterbitkan, Universiti Malaya, Kuala Lumpur).

[38] McCroskey, J. C., Richmond, V. P., \& Bennet, V. E. (2006). The relationship of student ends of class motivation with teacher communications behaviours and instructional outcomes. Communication Education,55(4). Retrieved from

http://www.jamescmccroskey.com/publications/221.pdf

[39] McCroskey, J. C., Richmond, V. P., Sallinen, A., Fayer, J. M., \& Barraclough, R. A. (1995). A cross cultural and multi behavioral analysis of the relationship between nonverbal immediacy andteacher evaluation.Communica, 44.

[40] Mehrabian, A. (1981). Silent messages; Implicit communication of emotion and attitudes. Belmont, CA: Wadsworth

[41] Mohamad Salleh Lebar. (1999). Memahami Psikologi. Batu Caves: Thinker's Library.

[42] Mok, S. S. (2003). Ilmu Pendidikan untuk KPLI (Komponen 1 \& 2) Sekolah Rendah: Psikologi pendidikan dan pedagogi. Subang Jaya: Kumpulan Budiman.

[43] Mok, S. S. (2011). Pedagogi untuk pengajaran dan pembelajaran. Puchong: Penerbitan Multimedia.

[44] Muhammad Al Amin Musa Ahmad. (2003). al ittisal ghair lafzi fi al Quran al Karim. al syariqah: dairah al thaqafah wal i'lam.

[45] Muhammad Azhar Zailani. (2007). Aktiviti komunikatif dalam pengajaran Bahasa Arab Sekolah Menengah. (Tesis PhDyang tidak diterbitkan, Universiti Malaya, Kuala Lumpur).

[46] Mustafa Daud. (1996). Bahasa dalam tamadun Islam. Kuala Lumpur: Dewan Bahasa Dan Pustaka.

[47] Nelson, I. (1997). Pengurusan masa untuk guru. (Terj. Anuar Ayub). Kuala Lumpur: Institut Terjemahan Negara Malaysia.

[48] Noor Hasnoor Mohamad Nor. (2001). Perkaitan antara kognisi, bahasa dan komunikasi: Satu kajian kes. (Disertasi sarjana yang tidak diterbitkan, Universiti Malaya,Kuala Lumpur).

[49] Noraini Idris. (2005). Pedagogi Dalam Pendidikan Matematik. Kuala Lumpur: Utusan.

[50] Nur Shafrin Ahmad, Rahimi Che Aman, \& Fadzilah Amzah. (2009). Komunikasi lisan dan bukan Lisan Dalam Kalangan Guru Pelatih. In Hasuria Che Omar, Rokian Awang, Syed Zainal Ariff Syed Jamaluddin, \& Noriah Mohamed (Eds.), Bahasa verbal dan bukan verbal I: Komunikasi, pendidikan dan penterjemahan. Kuala Lumpur: Institut Terjemahan Negara Malaysia.

[51] Paul, L. W., \& Lawrence, R. W. (2001). An experimental study of teachers' verbal and nonverbal immediacy and students' affective and cognitive learning. Communication Education, 50(4), 327-342. Retrieved from http://www.tan dfonline.com/doi/abs/10.1080/03634520109379259\#.UjZp -X-ZiuI 
[52] Pogue, L. L., \& Ahyun, K. (2006). The effectof teacher nonverbal immediacy and credibility on student motivation and affective learning. Communication Education, 55(33).

[53] Preacher, K. J., \& Selig, J. P. (2012). Advantages of Monte Carlo Confidence Intervals for Indirect Effects. Communication Methods and Measures, 6(2), 77-98. doi:1 $0.1080 / 19312458.2012 .679848$

[54] Ramlah Jantan, \& Mahani Razali. (2004). Psikologi Pendidikan: Pendekatan kontemporari(Edisi Revisi). Kuala Lumpur: McGraw-Hill.

[55] Reeve, J. (2009). Understanding motivation and emotion.New York, NY: Wiley.

[56] Richmond, V. P., \& McCroskey, J. C. (2000). Nonverbal behavior in interpersonal relations (4th ed.). Boston, MA: Allyn \& Bacon.

[57] Richmond, V. P., McCroskey, J. C., \& Johnsons, A. D. (2003). Development of The Nonverbal Immediacy Scale (NIS): Measures of self- and other- percieved nonverbal immediacy. Communication Quarterly, 51(4), 504-517. Retrieved from https://www.ffri.hr/ ibrdar/komunikacija/s eminari/McCroskey, 2003 - Nonverbal immediacy scale.pdf

[58] S. Nasution. (1995). Didaktif asas-asas mengajar. Jakarta: Bumi Aksara.

[59] Shahabuddin Hashim, Rohizani Yaakub, \& Mohd Zohir Ahmad. (2003). Pedagogi: Strategi dan teknik mengajar dengan berkesan. Bentong: PTS.

[60] Sperder, D., \& Wilson, D. (1999). Relevans komunikasi dan kognisi. (Terj. Nor Hashimah Jalaludin, Ed.). Kuala Lumpur: Dewan Bahasa dan Pustaka.

[61] Syed Ismail Syed Mustafa, \& Ahmad Subki Maskon. (2010). Budaya dan pembelajaran. Puchong: Penerbitan Multimedia.

[62] Zaidatol Akmaliah Lope Pihie. (2001). Pentadbiran pendidikan. Shah Alam: Fajar Bakti.

[63] Zulkifli Abdullah. (1999). Komunikasi nonverbal di kalangan masyarakat Melayu Besut. Kuala Lumpur.(Disertasi Sarjana yang tidak diterbitkan). Universiti Malaya.

[64] Zuraida Mohamed. (2011). Aspirasi murid seklah menengah dalam mata pelajaran Bahasa Arab. (Disertasi sarjana yang tidak diterbitkan). Kuala Lumpur: Universiti Malaya. 